\title{
Impact of strategic leadership on organizational performance, strategic orientation and opera- tional strategy
}

\section{Elif Bilginoğlua and Ugur Yozgat ${ }^{b^{*}}$}

${ }^{a}$ Istanbul, Turkey

${ }^{b}$ Istanbul Kultur University, Turkey

\begin{tabular}{l}
\hline C H R O N I C L E \\
\hline Article history: \\
Received: July 20, 2018 \\
Received in revised format: July \\
21,2018 \\
Accepted: September 11, 2018 \\
Available online: \\
September 12, 2018 \\
\hline Keywords: \\
Job stress \\
Perceived organizational sup- \\
port \\
Emotional intelligence \\
Job performance \\
\hline
\end{tabular}

\section{A B S T R A C T}

\begin{abstract}
This paper examined the relationship between job stress and job performance, along with the moderating effect of emotional intelligence (EI) and perceived organizational support (POS) among employees in the Istanbul financial sector. 564 employees and their 78 immediate supervisors were surveyed. The findings of this study suggest that job stress was negatively associated with job performance, where EI and POS were able to reduce the effect of stress on job performance. The results largely support the significant impact of job stress on job performance, moderated through EI and POS as hypostasized. This paper demonstrates the important role of the job stress on job performance which contributes to conceptual understanding of organizational efficiency. The study has used self-reports- as well as supervisor reports to study the effects of job stress on organizational performance.
\end{abstract}

C 2018 by the authors; licensee Growing Science, Canada

\section{Introduction}

Coleman (1976) called the modern age as "Age of Anxiety and Stress". Financial sector employees likely spend an overwhelming part of their works dealing with job stress. Some reasons of their job stress were dwindling job security, the responsibilities, heavier workloads, longer working hours, the external pressures to deliver consistent high performing results, and the regulatory upheaval. The global financial crisis which continues in many countries today (Cruise \& Davies, 2016; Giorgi et al., 2015; Goodman \& Mance, 2011; International Labour Office, Geneva, 2013, p. 5; Landsman, 2016; Tsai \& Chan, 2011, p. 446; United Nations, 2009) and the rapid economic changes have caused economic stressors such as heavier workloads, sales targets ignoring the tougher economic environment, job insecurity, job loss, unemployment and underemployment (Ellyatt, 2013; Fotinatos-Ventouratos \& Cooper, 2015, p. 3; Goodway, 2013; International Labour Office, Geneva, 2009; Kenth, 2015; Klehe et al., 2015, p.132; UNI Finance Global Union, 2012) which undermines their job performance (Shaikh et al., 2013, pp. 294-295). While there is too much pressure on industry players, the organizations need to understand whether the employees experiencing the negative effects of job stress may benefit from a high emotional quotient (EQ) and the support from their organizations and perform much better.

* Corresponding author.

E-mail address: uguryozgat@marmara.edu.tr (U. Yozgat)

C 2018 by the authors; licensee Growing Science, Canada doi: $10.5267 /$ j.msl.2018.9.007 


\section{Literature Review}

\subsection{Job Performance (JP)}

Job performance which is directly related to the level of energy and the specific form of action characterizing a worker's behavior (Mitchell et al., 1987, p. 31) is the most widely studied criterion variable in the organizational behavior and human resource management studies (Bommer et al., 1995, p. 587). Job performance is defined as "the total expected value to the organization of the discrete behavioral episodes that an individual carries out over a standard period" (Motowidlo, 2003) and refers to an individual's contribution to the organizational goals varying in meaning and importance (Marcus \& Schuler, 2004).

\subsection{Job Stress (JS)}

Job stress has been defined as an individual's reactions to characteristics of the work environment that appear emotionally and physically threatening (Jamal, 2005) or the harmful physical and emotional responses that occur when the requirements of the job do not match the capabilities, resources or the workers' needs (Sauter et al., 1999). It is an extension of general stress. However it is specifically a consequence of work settings (Jou et al., 2013, p. 97). Job stress is pervasive and is not confined to particular sectors, jobs or industries (What is Stress?, 2017). Since stress contributes to organizational inefficiency, the researchers propose:

$\mathrm{H}_{1}$ : Job stress has a negative effect on job performance.

\subsection{Emotional Intelligence (EI)}

Emotional intelligence has been defined as "abilities such as being able to motivate oneself and persist in the face of frustrations; to control impulse and delay gratification; to regulate one's moods and keep distress from swamping the ability to think; to emphasize and to hope" (Goleman, 1995, p.14) or as the set of verbal and nonverbal abilities that enable a person to generate, recognize, express, understand, and evaluate their own, and others, emotions in order to guide thinking and action that successfully cope with environmental demands and pressures (Van Rooy \& Viswesvaran, 2004, p. 72).

Today, the profile of emotions in the workplace is increasing in prominence (Domagalski, 1999, pp. 833834). Several studies point on how important emotional quotient (EQ) can be to excellent performance, even trumping intelligence quotient (IQ), technical skills and experience (Cartwright \& Pappas, 2008, p. 149; Cherniss, 2000, p. 10; Deutschendorf, 2015; Goleman, 1998b, p. 84; Lynn, 2008, p. 1; Strickland, 2000; Van Rooy \& Viswesvaran, 2004). It also appears from the findings of some studies that the employees who have higher levels of EI, experience significantly less stress at work than the ones who have lower levels of EI because managing one's own emotions ability has a significant effect on managing job stress (Bar-On, 1997; Ciarrochi et al. 2002; Gohm et al., 2005; Goleman, 1995; King \& Gardner, 2006; Min, 2013; Nikolaou \& Tsaousis, 2002; Por et al., 2011; Slaski \& Cartwright, 2002). Based on the fact that the ability to manage one's own emotions plays an extremely important role in managing job stress and managing and reducing stress helps to facilitate performance, the researchers propose:

$\mathrm{H}_{2}$ : Emotional intelligence moderates job stress - job performance relationship.

\subsection{Perceived Organizational Support (POS)}

Perceived organizational support refers to how much the employees' contributions to the organization is valued by the organization and how much the organizations cares for the employees' well-being (Eisenberger, Huntington et al., 1986, p. 501; Erdoğan \& Enders, 2007). Perceived organizational support performance link is mainly based on social exchange theory (Blau, 1964) and on the norm of reciprocity (Gouldner, 1960) by many researchers (Armeli et al., 1998; Duke et al., 2009; Eisenberger et al., 1986; 
Hekman, Bigley, Steensma \& Hereford, 2009; Hochwarter et al., 2006; Rhoades \& Eisenberger, 2002; Wayne et al., 1997). It is proposed that the individuals, who work for supportive organizations, believe that their time and effort investments are relatively safe. These employees are expected to raise their job performance (Randal et al., 1999, p. 162). POS will also result in the employees' thinking that their organizations will provide them with the resources that they might need to manage their job stress and so it may serve as an important resource for reducing stress (George et al., 1993, p. 160). Thus:

$\mathrm{H}_{3}$ : Perceived organizational support moderates job stress - job performance relationship.

\section{Method}

\subsection{Proposed Model}

The proposed model is shown in Fig. 1.

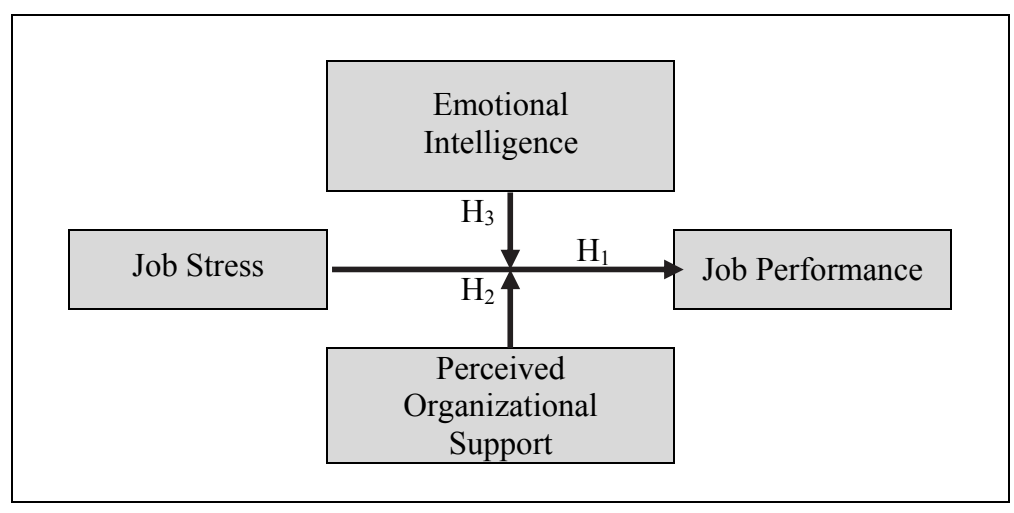

\subsection{Sample Design}

Fig. 1. Proposed research model

This study was carried out in the financial sector in Istanbul, Turkey. The researchers have narrowed down the scope of the private financial sector to five main industries, namely banking, participation banking, investment, leasing and factoring. Quoted convenient sampling method was used and considering the number of employees in each branch, 400 questionnaires were distributed to bankers, whilst 100 to each of the rest of the branches were distributed. 596 questionnaires $(85.1 \%)$ were returned from a total of 700 questionnaires which were provided for distribution. Unusable semi-filled questionnaires were discarded and the remaining 564 questionnaires (80.6\%) were analyzed using SPSS and LISREL statistical programs. Regarding socio-demographical aspects of the 564 employees of the financial sector in Istanbul, sample consisted of 308 females (54.6\%) and 256 males (45.4\%). Respondents averaged 32.72 years of age $(\mathrm{SD}=5.66)$ and 6.86 years of tenure $(\mathrm{SD}=4.98)$. Second, immediate supervisors of the respondents (78 in total) were surveyed to evaluate their employees' performance. The number of respondents per supervisor ranged between 4 and 12. Originally an English prepared surveys were translated into Turkish. To ensure validity and avoid cultural bias, the Turkish versions were back-translated (Brislin et al., 1973). Pretest revisions increased readability of the questions and data quality. By all the survey rounds, to minimize social desirability or acquiescence biases confidentiality was guaranteed, and asked them to honestly answer the questions (Spector, 2006). Surveys were collected in closed envelopes to decrease the social desirability biases.

\subsection{Measures}

Perceived Organizational Support. For measuring the employees' perceived support from their organizations 8-item short version of the Survey of Perceived Organizational Support (SPOS) which as developed by Eisenberger et al. (1986) was used. Sample items include "The organization strongly considers my goals and values." and "The organization cares about my opinions." Respondents indicated their level 
of agreement using 5-point Likert-type scale ( $1=$ strongly disagree, $5=$ strongly agree). Worley et al. (2009) verified the validity of this scale, and the Turkish translation was justified by Selçuk (2003).

Job Stress. JS is measured using the 13- item questionnaire (Parker \& DeCotiis, 1983). Sample items include "I frequently get the feeling I am married to the company." and "Too many people at my level in the company get burned out by job demands."

Emotional Intelligence. EI is measured by the 33- item Self-Report Emotional Intelligence Test (SREIT) (Schutte at al., 1998). Sample items include "I have control over my emotions." and "I easily recognize my emotions as I experience them." Authors prefer using one factor model as the original scale of Schutte et al. (1998), where three and more aspects like emotion perception, managing self- relevant emotions utilizing emotions and managing others' emotions were explored (Schutte et al., 2009). In this study original one factor model is preferred.

Job Performance. JP is measured by the 6 -item scale which is developed by Dubinsky and Mattson (1979) and modified by Singh et al. (1996). While in many cases, the view of the individuals' own job performance is quite different than that is valued by others (Thornton, 1980, p. 268) and while research suggests that supervisor ratings of employee job performance are more realistic and predictive (Atkins $\&$ Wood, 2002), the scale was adapted for the supervisors to rate the employee's performance. The supervisors rated their subordinate's job performance. Sample items include "How do you rate employee $\mathrm{X}$ in terms of his/her performance potential among the other employees in your company?" and "How do you rate employee X in terms of quality of his/her performance in regard to management of time?"

Control Variable. As job tenure is often used as a control variable in investigations of how other variables affect performance ( $\mathrm{Ng} \&$ Feldman, 2013), in the present study, the participants' job tenure was also selected as a control variable. As gained experience helps employees learn and enhance their skills, the job tenure has been found to have a positive impact on job performance by previous studies (Schmidt $\&$ Hunter, 2004).

\section{Results}

\subsection{Confirmatory Factor Analysis (CFA)}

The discriminant validity of our four variables (POS, job stress, EI, and job performance) with 60 items was examined using Lisrel. In the current study, we tested for the effect of common method bias by conducting Harman's ex-post one-factor test (Podsakoff \& Organ, 1986). All the variables used in the study were entered into an un-rotated factor analysis. The analysis has shown that there were 4 factors (with eigenvalues greater than 1.0), which explained 66.4 per cent of the variance. Harman's single factor test (Podsakoff et al., 2003) was also used to compare the fit of the model. The hypothesized model demonstrated a reasonably good fit to the data: $\chi 2(318)=809.59, \chi 2 / \mathrm{df}=1.44, \mathrm{RMSEA}=0.05, \mathrm{NFI}=$ $0.93, \mathrm{CFI}=0.94, \mathrm{GFI}=0.90, \mathrm{SRMR}=0.05$. Several alternative measurement models were examined, but these models have shown an unsatisfactory and/or a poorer fit. Thus, we treated the four variables of our study as being distinct in subsequent analyses.

\subsection{Descriptive Statistics and Intercorrelations}

Descriptive statistics of the variables JP, JS, EI and POS, their Cronbach's alpha values and correlations are shown in Table 1. 
Table 1

Descriptive statistics, Cronbach's Alpha Coefficients, and Correlations among Study Variables

\begin{tabular}{|c|c|c|c|c|c|c|}
\hline Variable & $M$ & $S D$ & 1 & 2 & 3 & 4 \\
\hline 1. JP & 3.96 & .67 & $(.90)$ & & & \\
\hline 2. JS & 2.78 & .96 & $-.18^{* * *}$ & $(.95)$ & & \\
\hline 3. EI & 4.05 & .62 & $.41^{* * *}$ & -.08 & $(.88)$ & \\
\hline 4. POS & 3.05 & .85 & $.27^{* * *}$ & $-.33^{* * *}$ & $.17^{* * *}$ & $(.90)$ \\
\hline
\end{tabular}

Note: $J P=$ Job Performance; JS = Job Stress; EI = Emotional Intelligence; POS = Perceived Organizational Support. Values on the diagonal represent Cronbach's alpha coefficients. ${ }^{*} p<.05,{ }^{* *} p<.01,{ }^{* * *} p<.001$ (two-tailed tests); $N=564$.

The highly positive correlated variables raised concerns regarding multi-collinearity. The variance inflation factor (VIF) values were used to test for multi-collinearity issues. Where values ranged from 1.61 to 3.89, multi-collinearity threat was avoided (Hair et al., 1995; O'Brien, 2007). To test the hypothesis hierarchical regression analysis were used.

Table 2

Summary of Hierarchical Regression Analysis

\begin{tabular}{|c|c|c|c|c|}
\hline Variable & $\begin{array}{c}\text { Model } 1 \\
\beta\end{array}$ & $\begin{array}{c}\text { Model } 2 \\
\beta\end{array}$ & $\begin{array}{c}\text { Model } 3 \\
\beta \\
\end{array}$ & $\begin{array}{c}\text { Model } 4 \\
\beta \\
\end{array}$ \\
\hline \multicolumn{5}{|l|}{ Control Variable } \\
\hline Job Tenure & $.178^{* * *}$ & $.206^{* * *}$ & $.216^{* * *}$ & $.204^{* *}$ \\
\hline \multicolumn{5}{|l|}{ Main Effect Variables } \\
\hline Job Stress (JS) & & $-.207^{* * *}$ & $-.176^{* * *}$ & $-.956^{* * *}$ \\
\hline Emotional Intelligence (EI) & & & $.404^{* * *}$ & .013 \\
\hline Perceived Organizational Support (POS) & & & & \\
\hline \multicolumn{5}{|l|}{ Interaction Variables } \\
\hline $\mathrm{JS} * \mathrm{EI}$ & & & & $.819^{* * *}$ \\
\hline \multicolumn{5}{|l|}{ JS * POS } \\
\hline $\mathrm{R}^{2}$ & .032 & .074 & .236 & .264 \\
\hline$\Delta \mathrm{R}^{2}$ & $.032^{* * *}$ & $044^{* * *}$ & $.162^{* * *}$ & $.028^{* *}$ \\
\hline Variable & $\begin{array}{c}\text { Model } 5 \\
\beta\end{array}$ & $\begin{array}{c}\text { Model } 6 \\
\beta\end{array}$ & $\begin{array}{c}\text { Model } 7 \\
\beta\end{array}$ & $\begin{array}{c}\text { Model } 8 \\
\beta\end{array}$ \\
\hline \multicolumn{5}{|l|}{ Control Variable } \\
\hline Job Tenure & $.200^{* * *}$ & $.194^{* * *}$ & $.211^{* * *}$ & $.196^{* * *}$ \\
\hline \multicolumn{5}{|l|}{ Main Effect Variables } \\
\hline Job Stress (JS) & $-.133^{* *}$ & $-.423^{* * *}$ & $-.124^{* *}$ & $-.940^{* * *}$ \\
\hline Emotional Intelligence (EI) & & & $.381^{* * *}$ & .023 \\
\hline Perceived Organizational Support (POS) & $.200^{* * *}$ & -.120 & $.164^{* * *}$ & -.094 \\
\hline \multicolumn{5}{|l|}{ Interaction Variables } \\
\hline JS * EI & & & & $.626^{* * *}$ \\
\hline JS $*$ POS & & $.333^{* * *}$ & & $.235^{* * *}$ \\
\hline $\mathrm{R}^{2}$ & .114 & .133 & .260 & .288 \\
\hline$\Delta \mathrm{R}^{2}$ & $.040^{* *}$ & $.019^{* *}$ & $.024^{* *}$ & $.024^{* *}$ \\
\hline
\end{tabular}

Note: ${ }^{*} p<.05,{ }^{* *} p<.01,{ }^{* * *} p<.001$ (two-tailed tests); $N=564$.

Model 2 revealed a support to our baseline prediction that "Job stress has a negative effect on the job performance” $(\beta=-.207, \mathrm{p}=.000)$. Hypothesis 1 supported.

To test the predictions that EI and POS moderates job stress - performance relationship, a hierarchical regression analysis was conducted. Firstly, continuous measures were mean-centered (Aiken \& West, 1991; Cohen et al., 2003), then predictor variables were entered in the following order:

Emotional Intelligence; (i) control variable -job tenure (Model 1); (ii) independent variable - job stress (Model 2) (iii) independent variable - EI (Model 3); and (iv) their two-way interaction term (Model 4).

Perceived Organizational Support; (i) control variable -job tenure (Model 1); (ii) independent variable - job stress (Model 2) (iii) independent variable - POS (Model 5); and (iv) their two-way interaction term (Model 6). 
Emotional Intelligence \& Perceived Organizational Support; (i) control variable -job tenure (Model 1); (ii) independent variable - job stress (Model 2); (iii) independent variables - EI \& POS (Model 7); and (iv) their two-way interaction terms (Model 8).

As predicted,

(i) the 2-way interaction of job stress and EI on job performance was significant $(\beta=.819, \mathrm{p}<.001)$. Hypothesis 2 is supported. The nature of the 2-way interaction was illustrated in Fig. 2 and Fig. 3 using one standard deviation below and above the means for EI and POS for the predicted values of the job performance (Aiken \& West, 1991; Cohen et al., 2003).

(ii) the 2-way interaction of job stress and POS on job performance was significant $(\beta=.333, p<.001)$. Hypothesis 3 is supported. The nature of the 2-way interaction is illustrated in Fig. 3.

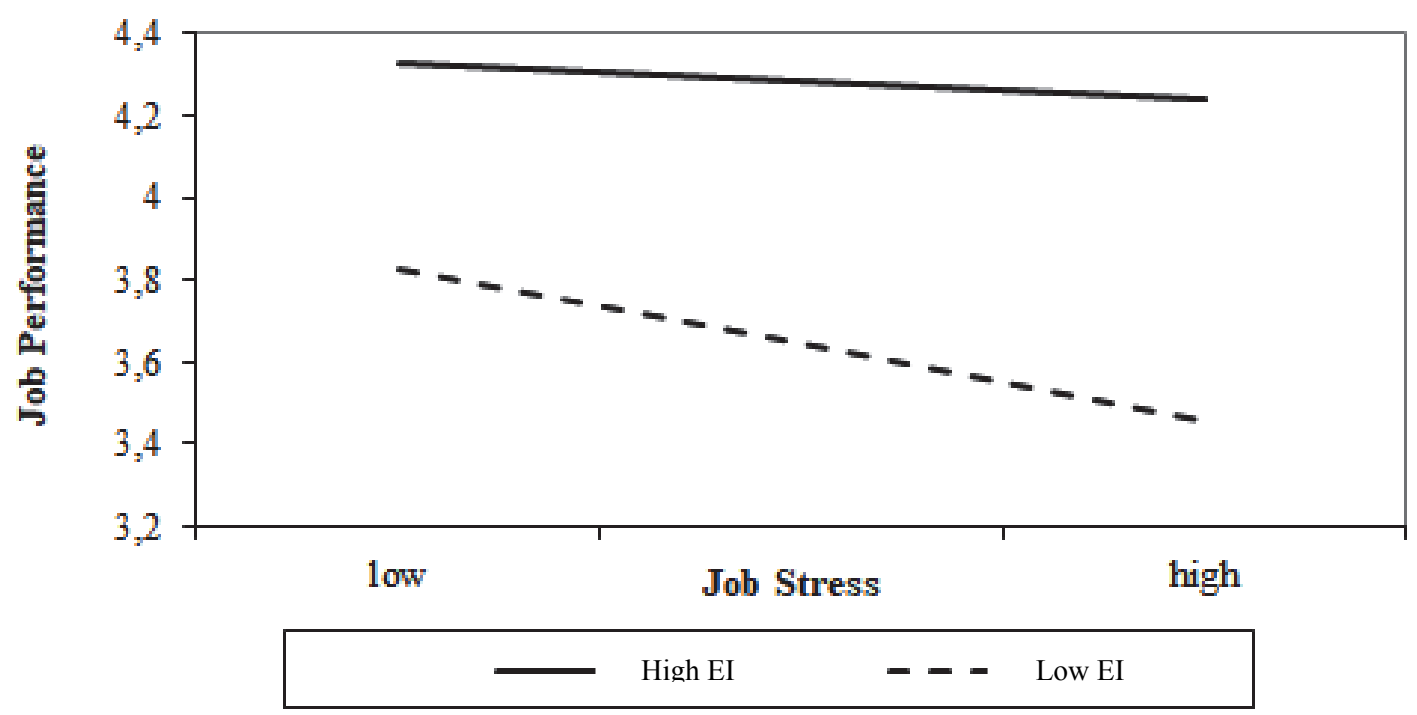

Fig. 2. Moderating effect of emotional intelligence (EI) on job stress - job performance relation

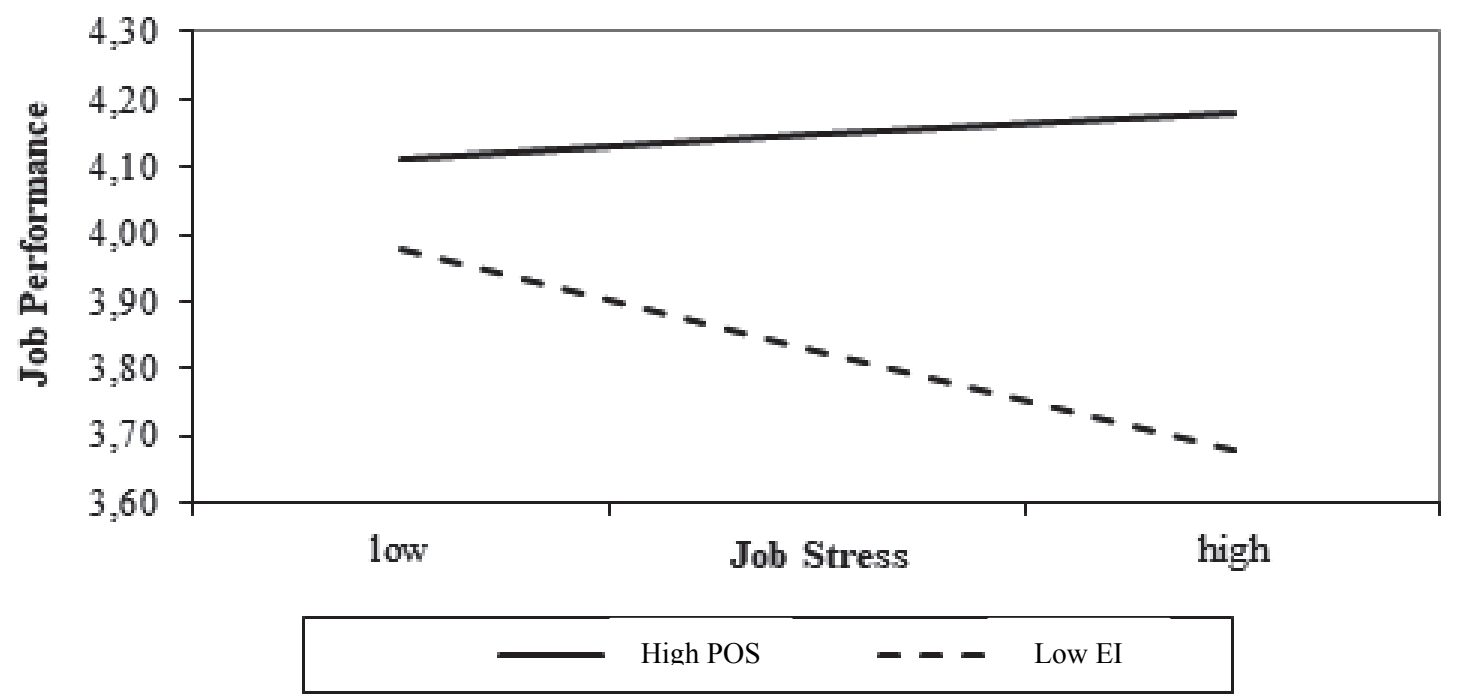

Fig. 3. Moderating effect of perceived organizational support (POS) on job stress - job performance relation 
To test the moderating effects, we also followed the procedures outlined by Preacher and Hayes (2004, 2008) and Hayes (2018) and constructed a 95\% bias-corrected confidence interval based on 10,000 bootstrap samples. Where the $95 \%$ confidence intervals did not include zero, providing evidence for significant indirect effects and, therefore, support for Hypothesis 2 and 3. This study has shown that financial sector employees' job stress decreases their job performance. Another finding is that both EI and POS have positive impact on job performance and both of them moderate the job stress - job performance relationship. The interaction effect of job stress and EI on job performance is shown in Fig. 2; EI reduces the decreasing effect of stress on job performance. The interaction effect of job stress and POS on job performance is shown in Fig. 3; POS was able considerably to reduce the decreasing effect of stress on job performance. Additionally, in case of high level of POS the effect of stress on job performance was neutralized. The three-way interaction terms (job stress $\times$ EI $\times$ POS) effect is also tested, but no significant effect was found.

\section{Discussion}

This paper has examined the moderating effect of EI and POS on the relationship between job stress and job performance among the financial sector employees. Although some researchers have indicated that stress - performance relationship is positive (e.g. Baddeley, 1972; Cohen, 1980; Stevenson \& Harper, 2006; LePine et al., 2005; Wetzel et al., 2006) or an inverted-U shape (e.g. Anderson, 1976), in line with the findings of the present study, most studies have found a negative relationship (e.g., Van Dyne et al., 2002; Siu, 2003; Gilboa et al., 2008; Bashir \& Ramay, 2010; Dar et al., 2011; Jamal, 2011; Jehangir et al., 2011; Wu, 2011; Yozgat et al., 2012; Arshadi \& Damiri, 2013; Yusoff et al., 2013). Besides, some studies have found no relation between the two variables (e.g., Chen et al., 2006; Manzoor et al., 2012).

The findings of our study have also revealed that the EI had a positive impact on job performance. These findings are consistent with the arguments of the researchers (Goleman, 1995, 1997, 1998a; 1998b; Bachman et al., 2000; Cherniss \& Goleman, 2001; Wong \& Law, 2002; Carmeli, 2003; Melita Prati et al., 2003; Stough \& DeGuara, 2003; Dulewicz et al., 2003; Higgs, 2004; Law et al., 2004; Carmeli \& Josman, 2006; Singh, 2006; Sy, Tram \& O'Hara, 2006; Law et al., 2008; McShane \& Steen, 2009; Huang et al., 2010; Downey et al., 2011; O’Boyle et al., Hawver \& Story, 2011) who have argued EI's positive effect on job performance.

Since the human resource is the most vital component that influences the productivity in an organization and so the employees are the source of attaining and sustaining the competitive edge, the organizations should do their best in order to prevent suffering from job stress which has serious implications for employee performance.

Considering the findings of both our initial and present study suggesting that the EI has a positive impact on job performance and it also moderates job stress - job performance relationship, the researchers suggest the Human Resources executives who are responsible for the hiring or the interviewing process, to include EI skills as part of their interview process. It should be kept in mind, that when technical skills are equal, EQ skills explain job success in many different positions. And because EQ can be taught, can be learnt and by this way, increase with deliberate practice and training (Slaski \& Cartwright, 2003, p. 238; Dulewicz \& Higgs, 2004; Bechara et al., 2007; Chamorro-Premuzic, 2013), in order to promote the present EI in organizations, it is suggested that a curriculum which helps to strengthen EI to be arranged by the training branch of the Human Resources department and some workshops to be held by them. Organizations may also offer their employees a combination of emotional intelligence and stress management trainings to help them be more compatible with stressful conditions and to deal with the requirements of their job more effectively. This will also end up in improving their job performance.

Consistent with many studies (e.g. Eisenberger et al., 1990; Wayne et al., 1997; Rogg, 1997; Randall et al., 1999; Lynch et al., 1999; Rhoades \& Eisenberger, 2002; Liu, 2004; Duke et al., 2009; Webster \& 
Adams, 2010; Jayawardana \& O’Donell, 2010; Sumathi, 2011; Stan et al., 2012), the findings have shown that POS had a positive impact on job performance and furthermore, it moderates job stress - job performance relationship among the financial sector employees.

Our findings also have shown that the EI of the financial sector employees had a positive impact on their job performance and the EI moderates job stress - performance relationship in this context. These findings are consistent with the findings of Law et al. (2008) and Lopes et al. (2006, p. 132) which assert that high EI may enable individuals recognize, regulate and use their emotions to manage their stress and thus they may perform well under pressure. Considering the association of POS with an increased propensity to experience a positive daily mood at work, as well as a decreased propensity to experience negative feelings such as tension or stress day by day, the present study has found that POS moderates the relationship between job stress and job performance. The organizations with the expectancy that their employees perform at their maximum levels must ensure that their policies and practices strengthen their employees' support perceptions. Moreover, supervisors should make the employees see that the organizations do not only feel responsible for them, but also value them in having open communication with them so that they feel that their organizations have discretion over their problems and are ready to provide any possible assistance needed.

In this study evidenced moderating the effect of EI and POS on job stress - job performance relationship, supported the observation of Parker and DeCotiis (1983) that dispositional variables are associated with perceived stress, and that they moderate the effect of stress outcomes within an organization. Although the study of Turunç and Çelik (2010) determined that both POS and job stress do not have a significant effect on job performance, in the study of Stamper and Johlke (2003) POS is not found to be related to performance and has moderating effects on several role stress - outcome relations.

\section{Limitations and Future Research}

Although Cotton and Hart (2003, p. 125) suggest that it is more important for organizations to make interventions for organizational support, rather than job stress reducing activities for employees, the authors of this study claim that the POS has a potential to reduce the stress in the workplace and this is an important area for further detailed investigations. Further research should certainly explore a comparison of the private and public sector in the same study.

This study is not without limitations. The limitation in this study was its focus on the role of job stress and job performance among the employees of one industry in one city only. For generalization, studies should be replicated region and/or country based among financial sector employees and/or other sector employees. Considering the quote of Singh (2006, p. 26) "A manager who is unaware of his/her impact on others is a walking disaster at the workplace.", the researchers suggest to measure the impact of the supervisors, who act as the agents of organizations in treating the subordinates (Eisenberger et al., 2002, p. 566). Thus, the future research should be directed at the proposed linkage between perceived supervisor support and the job stress - job performance relationship.

\section{References}

Aiken, L., \& West, S. (1991). Multiple Regression: Testing and Interpreting Interactions. CA: Sage Publishers.

Anderson, C. R. (1976). Coping behaviors as intervening mechanisms in the inverted-U stress-performance relationship. Journal of Applied Psychology, 61(1), 30.

Armeli, S., Eisenberger, R., Fasolo, P., \& Lynch, P. (1998). Perceived organizational support and police performance: The moderating influence of socioemotional needs. Journal of applied psychology, 83(2), 288. 
Arshadi, N., \& Damiri, H. (2013). The relationship of job stress with turnover intention and job performance: Moderating role of OBSE. Procedia-Social and Behavioral Sciences, 84, 706-710.

Atkins, P.W.B., \& Wood, R.E. (2002). Self-versus others' ratings as predictors of assessment center ratings: validation evidence for 360-degree feedback programs. Personnel Psychology, 55(4), 871904.

Bachman, J., Stein, S., Campbell, K., Sitarenios, G. (2000). Emotional intelligence in the collection of debt. International Journal of Selection and Assessment, 8, 176-182. http://dx.doi.org/10.1111/14682389.00145.

Baddeley, A. D. (1972). Selective attention and performance in dangerous environments. British journal of psychology, 63(4), 537-546.

Bar-On, R. (1997). Bar-On Emotional Quotient Inventory: A Measure of Emotional Intelligence. Technical Manual, Toronto: Multi-Health Systems.

Bashir, U., Ramay, M.I. (2010). Impact of stress on employees job performance: A study on banking sector of Pakistan. International Journal of Marketing Studies, 122-126.

Bechara, A., Damasio, A. R., Bar-On, R. (2007). The anatomy of emotional intelligence and implications for educating people to be emotionally intelligent In R. Bar-On, J.G. Maree, M. J. Elias (Eds.) Educating People to Be Emotionally Intelligent (273- 290). Westport: Praeger.

Blau, P.M. (1964). Exchange and Power in Social Life. New York: Wiley.

Bommer, W. H., Johnson, J. L., Rich, G. A., Podsakoff, P. M., \& MacKenzie, S. B. (1995). On the interchangeability of objective and subjective measures of employee performance: A meta-analysis. Personnel psychology, 48(3), 587-605.

Brislin, R. W., Lonner, W., Thorndike, R. M. (1973). Crosscultural Research Methods. New York: John Wiley \& Sons.

Carmeli, A. (2003). The relationship between emotional intelligence and work attitudes, behavior and outcomes: An examination among senior managers. Journal of managerial Psychology, 18(8), 788813.

Carmeli, A., \& Josman, Z. E. (2006). The relationship among emotional intelligence, task performance, and organizational citizenship behaviors. Human performance, 19(4), 403-419.

Cartwright, S., \& Pappas, C. (2008). Emotional intelligence, its measurement and implications for the workplace. International Journal of Management Reviews, 10(2), 149-171.

Chamorro-Premuzic, T. (2013). Can you really improve your emotional intelligence. Harvard Business Review, 91, 37-41.

Chen, J. C., Silverthorne, C., \& Hung, J. Y. (2006). Organization communication, job stress, organizational commitment, and job performance of accounting professionals in Taiwan and America. Leadership \& organization Development journal, 27(4), 242-249.

Cherniss, C. (2000, April). Emotional intelligence: What it is and why it matters. In annual meeting of the Society for Industrial and Organizational Psychology, New Orleans, LA(Vol. 15).

Cherniss, C., \& Goleman, D. (2001). The Emotionally Intelligent Workplace. San Francisco, CA: JoseyBass.

Ciarrochi, J., Deane, F. P., \& Anderson, S. (2002). Emotional intelligence moderates the relationship between stress and mental health. Personality and individual differences, 32(2), 197-209.

Cohen, S. (1980). Aftereffects of stress on human performance and social behavior: a review of research and theory. Psychological bulletin, 88(1), 82.

Cohen, J., Cohen, P., West, S. G., \& Aiken, L. S. (2003). Applied Multiple Regression/Correlation Analysis for the Behavioral Sciences (3rd ed.). New Jersey: Lawrence Erlbaum Associates, Inc.

Coleman, J.C. (1976). Abnormal Psychology and Modern Life, Taraporewalla, Bombay.

Cotton, P., \& Hart, P. M. (2003). Occupational wellbeing and performance: A review of organisational health research. Australian Psychologist, 38(2), 118-127.

Cruise, S., \& Davies, A. (2016, February 15). Stress and the city: Britain's bank workers buckle under pressure, Reuters Business News, Retrieved from http://www.reuters.com/article/us-britain-bankingstress-insight-idUSKCNOVNOAZ, 
Dar, L., Akmal, A., Naseem, M. A., \& din Khan, K. U. (2011). Impact of stress on employees job performance in business sector of Pakistan. Global journal of management and business research, 11(6), $1-4$.

Deutschendorf, H. (2015). Why emotionally intelligent people are more successful. Fast Company.

Domagalski, T.A. (1999). Emotion in organizations, Human Relations, 52, 833-852.

Downey, L. A., Lee, B., \& Stough, C. (2011). Recruitment consultant revenue: Relationships with IQ, personality, and emotional intelligence. International Journal of Selection and Assessment, 19(3), 280-286.

Dubinsky, A. J., \& Mattson, B. E. (1979). Consequences of role-conflict and ambiguity experienced by retail salespeople. Journal of Retailing, 55(4), 70-86.

Duke, A. B., Goodman, J. M., Treadway, D. C., \& Breland, J. W. (2009). Perceived organizational support as a moderator of emotional labor/outcomes relationships. Journal of Applied Social Psychology, 39(5), 1013-1034.

Dulewicz, V., Higgs, M., \& Slaski, M. (2003). Measuring emotional intelligence: Content, construct and criterion-related validity. Journal of Managerial Psychology, 18(5), 405-420.

Dulewicz, V., \& Higgs, M. (2004). Can emotional intelligence be developed?. The International Journal of Human Resource Management, 15(1), 95-111.

Eisenberger, R., Huntington, R., Hutchison, S., \& Sowa, D. (1986). Perceived organizational support. Journal of Applied psychology, 71(3), 500.

Eisenberger, R., Fasolo, P., \& Davis-LaMastro, V. (1990). Perceived organizational support and employee diligence, commitment, and innovation. Journal of applied psychology, 75(1), 51.

Eisenberger, R., Stinglhamber, F., Vandenberghe, C., Sucharski, I. L., \& Rhoades, L. (2002). Perceived supervisor support: Contributions to perceived organizational support and employee retention. Journal of applied psychology, 87(3), 565.

Ellyatt, H. (2013, October 16). Financial workers fall sick due to stress, Retrieved from http://www.cnbc.com/2013/10/16/financial-workers-fall-sick-due-to-stress.html,

Erdogan, B., \& Enders, J. (2007). Support from the top: Supervisors' perceived organizational support as a moderator of leader-member exchange to satisfaction and performance relationships. Journal of applied psychology, 92(2), 321.

Fotinatos-Ventouratos, R., Cooper, C.L. (2015). The Economic Crisis and Occupational Stress. UK: Edward Elgar Publishing.

George, J. M., Reed, T. F., Ballard, K. A., Colin, J., \& Fielding, J. (1993). Contact with AIDS patients as a source of work-related distress: Effects of organizational and social support. Academy of Management Journal, 36(1), 157-171.

Gilboa, S., Shirom, A., Fried, Y., \& Cooper, C. (2008). A meta-analysis of work demand stressors and job performance: examining main and moderating effects. Personnel Psychology, 61(2), 227-271.

Giorgi, G., Arcangeli, G., Mucci, N., \& Cupelli, V. (2015). Economic stress in the workplace: the impact of fear of the crisis on mental health. Work, 51(1), 135-142.

Gohm, C. L., Corser, G. C., \& Dalsky, D. J. (2005). Emotional intelligence under stress: Useful, unnecessary, or irrelevant?. Personality and individual differences, 39(6), 1017-1028.

Goleman, D. (1995). Emotional Intelligence, New York: Bantam Books.

Goleman, D. (1998b). What makes a leader? Harvard Business Review, November-December, 82-91.

Goodman, C. J., \& Mance, S. M. (2011). Employment loss and the 2007-09 recession: an overview. Monthly Labor Review, 134(4), 3-12.

Goodway, N. (2013, October 17). Stress and job cuts take toll on bankers, Independent, Retrieved from $\mathrm{http}: / / \mathrm{www}$. independent.co.uk/news/business/analysis-and-features/stress-and-job-cuts-take-toll-onbankers-8885045.html.

Gouldner, A. W. (1960). The norm of reciprocity: A preliminary statement. American Sociological Review, 25(2), 161-178.

Hair, J. F. Jr., Anderson, R. E., Tatham, R. L., \& Black, W. C. (1995). Multivariate Data Analysis. 3rd Ed. New York: Macmillan. 
Hayes, A. F. (2018). Partial, conditional, and moderated moderated mediation: Quantification, inference, and interpretation. Communication Monographs, 85(1), 4-40.

Hekman, D. R., Bigley, G. A., Steensma, H. K., \& Hereford, J. F. (2009). Combined effects of organizational and professional identification on the reciprocity dynamic for professional employees. Academy of management journal, 52(3), 506-526.

Higgs, M. (2004). A study of the relationship between emotional intelligence and performance in UK call centres. Journal of Managerial Psychology, 19(4), 442-454.

Hochwarter, W. A., Witt, L. A., Treadway, D. C., \& Ferris, G. R. (2006). The interaction of social skill and organizational support on job performance. Journal of Applied Psychology, 91(2), 482.

Huang, X., Chan, S. C., Lam, W., \& Nan, X. (2010). The joint effect of leader-member exchange and emotional intelligence on burnout and work performance in call centers in China. The International Journal of Human Resource Management, 21(7), 1124-1144.

International Labour Office, Geneva (2009). Impact of the Financial Crisis on Finance Sector Workers - Issues paper for discussion at the Global Dialogue Forum on the Impact of the Financial Crisis on Finance Sector Workers, Geneva, 24-25 February 2009, 1-24. Retrieved from http://www.ilo.org/wcmsp5/groups/public/@dgreports/@dcomm/documents/meetingdocument/wcms 103263.pdf,

International Labour Office, Geneva (2013). Protecting Workplace Safety and Health in Difficult Economic Times - The Effect of the Financial Crisis and Economic Recession on Occupational Safety and Health, 1-50. Retrieved from http://www.ilo.org/wcmsp5/groups/public/---ed_protect/---protrav/---safework/documents/publication/wcms_214163.pdf,

Jamal, M. (2005). Burnout among Canadian and Chinese employees: a cross-cultural study. European Management Review, 2(3), 224-230.

Jamal, M. (2011). Job stress, job performance and organizational commitment in a multinational company: An empirical study in two countries. International Journal of Business and Social Science, 2(20), 20-29.

Jayawardana, A., \& O'Donnell, M. (2010). Social exchange, organizational support and employee performance in Sri Lanka's garment industry. South Asian Journal of Management, 17(2), 7-28.

Jehangir, M., Kareem, N., Khan, A., Jan, M. T., \& Soherwardi, S. (2011). Effects of job stress on job performance and job satisfaction. Interdisciplinary journal of contemporary research in business, 3(7), 453-465.

Jou, R. C., Kuo, C. W., \& Tang, M. L. (2013). A study of job stress and turnover tendency among air traffic controllers: The mediating effects of job satisfaction. Transportation research part E: logistics and transportation review, 57, 95-104.

Kenth, J. (2015). Why the financial sector must face up to stress, Willis Resilience, 5, Retrieved from http://www.resilience.willis.com/articles/2015/01/08/why-stress-growing-drain-financial-sector/,

King, M., \& Gardner, D. (2006). Emotional intelligence and occupational stress among professional staff in New Zealand. International Journal of Organizational Analysis, 14(3), 186-203.

Klehe, U. C., Zikic, J., van Vianen, A. E., Koen, J., \& Buyken, M. (2012). Coping proactively with economic stress: Career adaptability in the face of job insecurity, job loss, unemployment, and underemployment. In The role of the economic crisis on occupational stress and well being (pp. 131-176). Emerald Group Publishing Limited.

Landsman, S. (2016, February 14). Think the Financial Crisis is over? Not for These Jobs, Retrieved from http://www.cnbc.com/2016/02/12/think-the-financial-crisis-is-over-not-for-these-jobs.html,

Law, K.S., Wong, C. \& Song L.J. (2004). The construct and criterion validity of EI and its potential utility for management studies. Journal of Applied Psychology, 89, 483-496.

Law, K. S., Wong, C. S., Huang, G. H., \& Li, X. (2008). The effects of emotional intelligence on job performance and life satisfaction for the research and development scientists in China. Asia Pacific Journal of Management, 25(1), 51-69.

Law, K. S., Wong, C. S., Huang, G. H., \& Li, X. (2008). The effects of emotional intelligence on job performance and life satisfaction for the research and development scientists in China. Asia Pacific Journal of Management, 25(1), 51-69. 
Liu, W. (2004). Perceived Organizational Support: Linking Human Resource Management Practices with Important Work Outcomes. Dissertation submitted to the Faculty of the Graduate School of the University of Maryland.

Lopes, P.N., Grewal, D., Kadis, J., Gall, M., \& Salovey, P. (2006). Evidence that emotional intelligence is related to job performance and affect and attitudes at work. Psicothema, 18, 132-138.

Lynch, P. D., Eisenberger, R., \& Armeli, S. (1999). Perceived organizational support: Inferior versus superior performance by wary employees. Journal of applied psychology, 84(4), 467.

Lynn, A.B. (2008). The EQ Interview: Finding Employees with High Emotional Intelligence. NewYork: Amacom.

Marcus, B., \& Schuler, H. (2004). Antecedents of counterproductive behavior at work: A general perspective. Journal of Applied Psychology, 89(4), 647.

Manzoor, A., Awan, H., \& Mariam, S. (2012). Investigating the impact of work stress on job performance: A Study on Textile Sector of Faisalabad. Asian journal of business and management sciences, 2(1), 20-28.

McShane, S. L., Steen, S. (2009). Canadian Organizational Behaviour. 7th Ed, Toronto: McGraw-Hill Ryerson.

Min, J. (2014). The relationships between emotional intelligence, job stress, and quality of life among tour guides. Asia Pacific Journal of Tourism Research, 19(10), 1170-1190.

Melita Prati, L., Douglas, C., Ferris, G. R., Ammeter, A. P., \& Buckley, M. R. (2003). Emotional intelligence, leadership effectiveness, and team outcomes. The International Journal of Organizational Analysis, 11(1), 21-40.

Mitchell, D.E.; Ortiz, F.I., Mitchell, T.K. (1987). Work Orientation and Job Performance: The Cultural Basis of Teaching Rewards and Incentives. Albany: State University of New York Press.

Motowidlo, S.J. (2003). Job Performance: In W.C. Borman, D.R. Ilgen and R.J. Klimoski (Eds), Handbook of Psychology: Industrial and Organizational Psychology - Volume 12 (39-53). New York: Wiley.

Ng, T. W., \& Feldman, D. C. (2013). Does longer job tenure help or hinder job performance?. Journal of Vocational Behavior, 83(3), 305-314.

Nikolaou, I., \& Tsaousis, I. (2002). Emotional intelligence in the workplace: Exploring its effects on occupational stress and organizational commitment. The International Journal of Organizational Analysis, 10(4), 327-342.

O'Boyle Jr, E. H., Humphrey, R. H., Pollack, J. M., Hawver, T. H., \& Story, P. A. (2011). The relation between emotional intelligence and job performance: A meta-analysis. Journal of Organizational Behavior, 32(5), 788-818.

O'brien, R. M. (2007). A caution regarding rules of thumb for variance inflation factors. Quality \& quantity, 41(5), 673-690.

Parker, D.F., DeCotiis, T.A. (1983). Organizational determinants of job stress. Organizational Behavior and Human Performance, 32, 160-167.

Podsakoff, P. M., MacKenzie, S. B., Lee, J. Y., \& Podsakoff, N. P. (2003). Common method biases in behavioral research: A critical review of the literature and recommended remedies. Journal of applied psychology, 88(5), 879.

Podsakoff, P. M., \& Organ, D. W. (1986). Self-reports in organizational research: Problems and prospects. Journal of management, 12(4), 531-544.

Por, J., Barriball, L., Fitzpatrick, J., \& Roberts, J. (2011). Emotional intelligence: Its relationship to stress, coping, well-being and professional performance in nursing students. Nurse education today, 31(8), 855-860.

Preacher, K. J., \& Hayes, A. F. (2004). SPSS and SAS procedures for estimating indirect effects in simple mediation models. Behavior research methods, instruments, \& computers, 36(4), 717-731.

Preacher, K. J., \& Hayes, A. F. (2008). Asymptotic and resampling strategies for assessing and comparing indirect effects in multiple mediator models. Behavior research methods, 40(3), 879-891.

Randall, M. L., Cropanzano, R., Bormann, C. A., \& Birjulin, A. (1999). Organizational politics and organizational support as predictors of work attitudes, job performance, and organizational citizenship 
behavior. Journal of Organizational Behavior: The International Journal of Industrial, Occupational and Organizational Psychology and Behavior, 20(2), 159-174.

Rhoades, L., \& Eisenberger, R. (2002). Perceived organizational support: a review of the literature. Journal of applied psychology, 87(4), 698.

Rogg, K. L. (1997). Organizational Commitment in the Post-loyalty Era: Perceived Organizational Support, Multiple Commitments and Other Antecedents' Effects on Turnover Intentions and Job Performance, Dissertation submitted to the Department of Psychology College of Arts and Sciences Kansas State University.

Sauter, S., Murphy, L., Colligan, M., Swanson, M., Hurrell, J., Scharf, F., Sicnlair, R., Grubb, P., Goldenhar, L., Alterman, T., Johnston, J., Hamilton, A., Tisdale, J. (1999). Stress At Work, NIOSH Publication No: 99-101. Retrieved from http://www.cdc.gov/niosh/docs/99-101/pdfs/99-101.pdf

Schmidt, F. L., \& Hunter, J. (2004). General mental ability in the world of work: occupational attainment and job performance. Journal of personality and social psychology, 86(1), 162.

Schutte, N. S., Malouff, J. M., Hall, L. E., Haggerty, D. J., Cooper, J. T., Golden, C. J., \& Dornheim, L. (1998). Development and validation of a measure of emotional intelligence. Personality and individual differences, 25(2), 167-177.

Schutte, N. S., Malouff, J. M., \& Bhullar, N. (2009). The Assessing Emotions Scale. In C. Stough, D. H. Saklofske, \& J. D. A. Parker (Eds.), Assessing Emotional Intelligence: Theory, Research and Application (pp. 119-134). New York: Springer.

Selçuk, G. (2003) Örgütsel Desteğin Çalı̧̧anların İş ile İlgili Tutumlarına Etkisi, Dokuz Eylül Üniversitesi, Sosyal Bilimler Enstitüsü, Yüksek Lisans Tezi.

Shaikh, A. A., Akram, M., Rizwan, M., Kousar, S., \& Malik, M. (2013). The Impact of job stress: An imperative insight into the Banking sector. Journal of Public Administration and Governance, 3(3), 294-316.

Singh, D. (2006). Emotional Intelligence at Work: A Professional Guide. New Delhi: Response Books.

Singh, J., Verbeke, W., \& Rhoads, G. (1996). Do organizational practices matter in role stress processes? A study of direct and moderating effects for marketing-oriented boundary spanners. Journal of Marketing, 60(3), 69-86.

Siu, O. L. (2003). Job stress and job performance among employees in Hong Kong: The role of Chinese work values and organizational commitment. International journal of psychology, 38(6), 337-347.

Slaski, M., \& Cartwright, S. (2002). Health, performance and emotional intelligence: An exploratory study of retail managers. Stress and Health: Journal of the International Society for the Investigation of Stress, 18(2), 63-68.

Spector, P. E. (2006). Method variance in organizational research: truth or urban legend?. Organizational research methods, 9(2), 221-232.

Stamper, C. L., \& Johlke, M. C. (2003). The impact of perceived organizational support on the relationship between boundary spanner role stress and work outcomes. Journal of Management, 29(4), 569588.

Stevenson, A., \& Harper, S. (2006). Workplace stress and the student learning experience. Quality Assurance in Education, 14(2), 167-178.

Stough, C., DeGuara, D. (2003). Examining the relationship between emotional intelligence and job performance. Australian Journal of Psychology, 55, 145.

Strickland, D. (2000). Emotional intelligence: the most potent factor in the success equation. Journal of nursing administration, 30(3), 112-117.

Sumathi, G.N. (2011). Perceived organizational support and job performance among medical personnel: A study in Indian public health care sector. 7th International Conference on Business, Management, and Economics - ICBME'11 e- proceeding, 6-8 October 2011, Çeşme - İzmir, Turkey.

Sy, T., Tram, S., \& O’Hara, L. A. (2006). Relation of employee and manager emotional intelligence to job satisfaction and performance. Journal of vocational behavior, 68(3), 461-473.

Thornton III, G. C. (1980). Psychometric properties of self-appraisals of job performance. personnel psychology, 33(2), 263-271. 
Tsai, F. J., \& Chan, C. C. (2011). The impact of the 2008 financial crisis on psychological work stress among financial workers and lawyers. International archives of occupational and environmental health, 84(4), 445-452.

Turunç, Ö., Çelik, M. (2010). Çalışanların algıladıkları örgütsel destek ve iş stresinin örgütsel özdeşleşme ve iş performansina etkisi. Yönetim ve Ekonomi, 17, 183-206.

United Nations (2009, July 13). General assembly - Sixty-third session - Agenda item 48 - Resolution adopted by the general assembly on 9 July 2009, 1-14;

UNI Finance Global Union (2012). Banking job loss survey: Job losses and restructuring process in the financial sector.

Van Dyne, L., Jehn, K. A., \& Cummings, A. (2002). Differential effects of strain on two forms of work performance: Individual employee sales and creativity. Journal of Organizational Behavior, 23(1), $57-74$.

Van Rooy, D. L., \& Viswesvaran, C. (2004). Emotional intelligence: A meta-analytic investigation of predictive validity and nomological net. Journal of vocational Behavior, 65(1), 71-95.

Van Rooy, D. L., \& Viswesvaran, C. (2004). Emotional intelligence: A meta-analytic investigation of predictive validity and nomological net. Journal of vocational Behavior, 65(1), 71-95.

Webster, J. R., \& Adams, G. A. (2010). Organizational support and contract fulfillment as moderators of the relationship between preferred work status and performance. Journal of Business and Psychology, 25(1), 131-138.

Wetzel, C. M., Kneebone, R. L., Woloshynowych, M., Nestel, D., Moorthy, K., Kidd, J., \& Darzi, A. (2006). The effects of stress on surgical performance. The American Journal of Surgery, 191(1), 510.

What is Stress? (2017). Retrieved from http://www.hse.gov.uk/stress/furtheradvice/wrs.htm

Wong, C. S., \& Law, K. S. (2002). The effects of leader and follower emotional intelligence on performance and attitude: An exploratory study. The leadership quarterly, 13(3), 243-274.

Worley, J. A., Fuqua, D. R., \& Hellman, C. M. (2009). The survey of perceived organisational support: Which measure should we use?. SA Journal of Industrial Psychology, 35(1), 112-116.

Wu, Y. C. (2011). Job stress and job performance among employees in the Taiwanese finance sector: The role of emotional intelligence. Social Behavior and Personality: an international journal, 39(1), 21-31.

Yozgat, U., Yurtkoru, S., \& Bilginoğlu, E. (2013). Job stress and job performance among employees in public sector in Istanbul: examining the moderating role of emotional intelligence. Procedia-Social and behavioral sciences, 75, 518-524.

Yusoff, R. B. M., Khan, A., \& Azam, K. (2013). Job stress, performance and emotional intelligence in academia. Journal of Basic and Applied Science Resesearch, 3(6), 1-8.

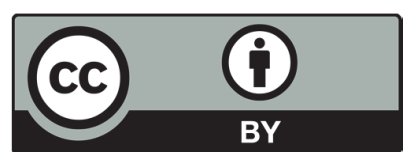

(C) 2018 by the authors; licensee Growing Science, Canada. This is an open access article distributed under the terms and conditions of the Creative Commons Attribution (CCBY) license (http://creativecommons.org/licenses/by/4.0/). 